\title{
NEW RODENTS AND NEW BATS FROM NEOTROPICAL REGIONS
}

\author{
By H. E. Anthony
}

Upon taking up work on collections of South American mammals accumulated in the American Museum during the past three years, several apparently undescribed forms have been discovered. They are hereby set forth in a preliminary paper, pending a detailed report on the entire collections which will be delayed for some months.

Acknowledgment is made of the kind loan of comparative material by Mr. Gerrit S. Miller, Jr., Curator, Division of Mammals, United States National Museum.

\section{Microsciurus septentrionalis sp. nov.}

Type, No. 41235, Dept. of Mammalogy, $q$, Sabalos, on Rio San Juan at junction of Rio Sabalos, Nicaragua, May 12, 1917; collector, Wm. B. Richardson.

Characters.-Similar to $M$. alfari in general appearance but with less rufescent pelage, above and below, and with post-palatal region noticeably longer and molar teeth smaller.

Color.-Upperparts presenting a grizzled olivaceous appearance, the hairs slate black at the base and tipped with honey yellow, top of head slightly more ochraceous; underparts warm buff; tail, above mixed cinnamon-rufous and black, the hairs being banded with alternate bands of each color and tipped with a yellow shade more like that of the light tipped hairs on the back, below very much as above.

Skull.-Like that of alfari but with longer palate, the post-palatal notch not reaching to plane of last molars.

Measurements (taken in the flesh).-Total length, $240 \mathrm{~mm} .(250) ; 1$ tail vertebræ, 100 (120); hind foot, 30 (30); hind foot measured from dry skin, with claws, 37 (37.3). Skull, occipito-nasal length, 33.7; zygomatic breadth, 21.6; breadth of braincase, 18.1; interorbital breadth, 14, length of nasals, 10 ; length of maxillary toothrow, 5.3.

The Nicaragua squirrel presents rather a puzzling problem as to affinities. Logically it should be closely related to alfari, the type locality of which is about 80 miles to the south, but in some characters it more closely resembles isthmius vivatus from Panama. The type of coloration of septentrionalis, olivaceus in general appearance, is well contrasted with the ferruginous pelage of alfari (type specimen) but compared with isthmius vivatus this difference is not very great in either the upper or lower parts.

${ }^{1}$ Measurements in parentheses are of topotype. 
In skull characters septentrionalis more nearly resembles isthmius vivatus, as these two forms, of all the Central American Microsciurus, alone have the post-palatal region extending beyond the plane of the last molar. This extension of the palate serves to separate septentrionalis from all forms but isthmius vivatus, but from this latter it is separated by smaller molars.

But two specimens of this squirrel were taken, both at Sabalos, $\sigma^{\pi}$ and o .

\section{Dactylomys boliviensis sp. nov.}

\section{Text figures 1 and 2}

Type, No. 38709, Dept. of Mammalogy, $q$, Mission San Antonio, Rio Chmore Prov. Cochabamba, Bolivia; altitude 1300 feet, August 18, 1915; collectors, Leo E. Miller and H. S. Boyle. The type is a well prepared skin with a perfect skull, fully mature and with molar crowns well worn.

General characters. - Similar to D. dactylinus but somewhat smaller and coloration a uniform olivaceous gray.

Color.-Upperparts, from between ears to base of tail, clothed with very long, lax hairs which are black at the base for three quarters of their length or more, and are tipped with buffy brown along the back and olive-buff on the sides, the general effect being difficult to describe but giving a distinctly olivaceous impression in most lights; crown with a patch of long clove brown hairs that form a sort of a hood extending as far as the ears; vibrissæ very long and black; underparts white to cream colored with narrow encroachments of the grizzled hair from the sides. Forelegs above, like rest of upperparts; below, like breast. Hind limbs, along inside and upper surface, cinnamon buff; below like belly. Tail very long, practically naked and scaly except for space of about $60 \mathrm{~mm}$. at the base, where the long hair of the back extends down onto the tail and is black in color, the tips of the hairs cream color.

Detailed characters.-Toes, five ${ }^{2}$ in front, five behind. Ears small, sparsely haired, almost hidden in long hair of head. Eyes small, with a tuft of long vibrissæ arising just posterior to the eye.

Skull.-Large and strongly built; nasals widening rapidly anteriorly, terminating almost in same plane with premaxillæ; superior outline of skull very flat; maxillary toothrows converging anteriorly almost to the midline; posterior portion of palate built out by a thin shelf-like extension of post palatal region; pterygoid processes very long, slender and meeting the auditory bullæ; other skull characters and mandible normal for the genus.

Measurements (taken in the field).-Total length, $710 \mathrm{~mm}$.; tail vertebræ, 410 ; hind foot, 60 ; greatest length of skull, 74.1; condylobasal length, 70.6; zygo-

2 The fifth toe of the fore foot is so small that a lens is required to distinguish it with certainty. It consists mainly of a vestigial claw set in the plantar tubercle that formerly lay at the base of that toe. 
matic breadth, 34; length of nasals, 21.5 ; greatest breadth of frontals, 22.5; greatest breadth of braincase, 23.2 ; length of palate, postpalatal notch to posterior border of incisive alveolus, 35.2; length of molar toothrow, 17.7; greatest length of mandible, 51.2 ; length of mandibular molar series, 18.3.

This new form of Dactylomys is noticeably different from the one specimen of $D$. dactylinus in the museum collections, and as nearly as I can judge from the literature on the genus, from any hitherto described form. A specimen of this genus, taken at Villavicencio, eastern

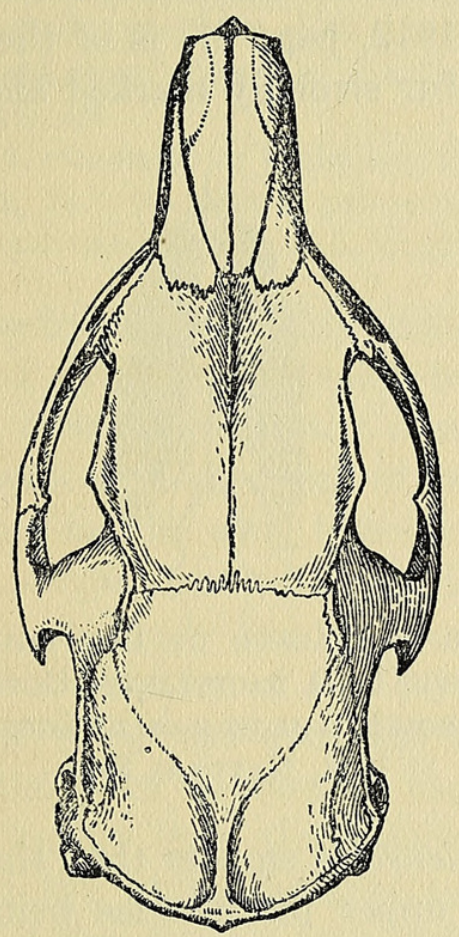

Fig. 1. Type of Dactylinus boliviensis, No. 38709 , Natural Size

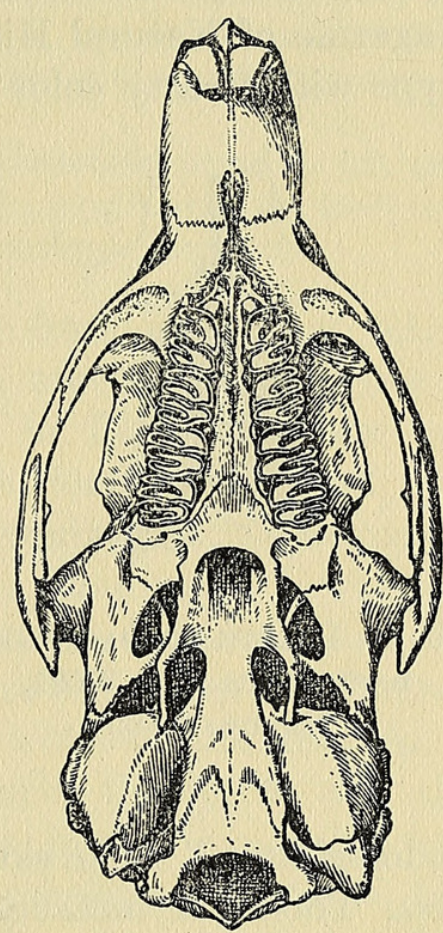

Fig. 2. Type of Dactylomys Boliviensis, No. 38709; NAtUral Size

base of the Andes, Colombia, was identified by Doctor Allen ${ }^{3}$ as dactylinus, with which it agrees in all characters of specific importance as well as can be expected when the basis for comparison is the short type description of Desmarest. ${ }^{4}$ Later authors have not extended Desmarest's account very appreciably.

The Bolivian specimen, compared with this specimen of dactylinus, is much more olivaceous in coloration, lacks the reddish brown at the

${ }^{3}$ Bull. Amer. Mus. Nat. Hist., XXXV, p. 208, 1916.

${ }^{4}$ Nouv. Dict. H. N., X, p. 57, 1817. 
base of the long hairs on the back, has much less ochraceous on the flanks and hind limbs, and differs particularly in skull characters in the greatly extended post palatal region. The enamel pattern of the molars is practically identical in dactylinus and boliviensis.

The palate of $D$. typus [ $=D$. dactylinus] figured in the Revue et Magasin de Zoologie for 1852, plate 16 (text figure 4), shows that the postpalatal region in dactylinus (text figure 3 ) is much shorter than in boliviensis and the same as in the museum specimen from Villavicencio. ${ }^{5}$

Dactylomys dactylinus canescens, described by Thomas in the Annals and Magazine of Natural History for 1912, page 87, is of the dactylinus type with "rusty color of under fur strongly marked along the

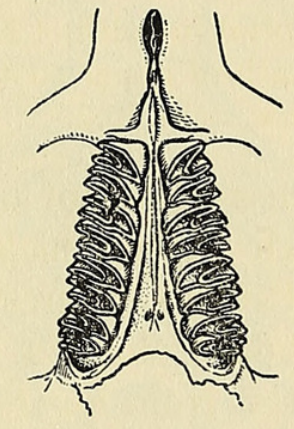

Fig. 3. Palate of Dactylomys DaCTYlinus, No. 34594, Natural Size

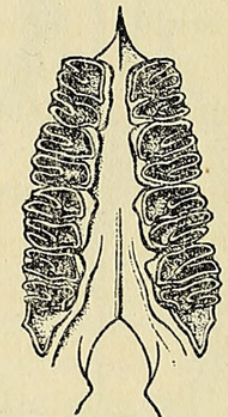

Fig. 4. Palate of Dactylomys TYPUS [ =D. DACTYLINUS], Copied From RevUe ET MAG. DE ZoOL., 1852, Natural Size

middle dorsal area." The skull of boliviensis is smaller than that of $d$. canescens, Thomas's measurement of upper tooth-series being 21.5 $\mathrm{mm}$. as against a length of $\mathbf{1 7 . 7}$ in boliviensis.

The type is the only specimen of this species secured.

\section{Chrotopterus colombianus sp. nov.}

Type, No. 38966, Dept. of Mammalogy, sex indet., Rio Quatequia, near Bogota, Colombia; collector, Hermano Apolinar Maria. The type is a complete skin with skull, the pelage being in good condition but the bones of both forearms are broken and not measurable. The type locality is on one of the upper tributaries of the Rio Meta about fifty miles to the east of Bogota.

Characters.- Size about as in auritus but darker brown above, yellowish brown instead of gray below, and tragus quite broad and blunt.

${ }^{5}$ The Villavicencio specimen has the posterior margin of the palate somewhat broken, so that the exact extent of the palate may be only approximated. 
Color.-Above, everywhere uniform Mars brown of Ridgway, the hairs minutely tipped with whitish and with the extreme bases lighter, on the neck and behind the ears the white at the base of the hairs is much more extensive and produces a lightening in the external color; below the hairs are snuff brown except for an irregular median area of cream buff and an extensive area on the throat and chest which is cream buff; membranes naked, brownish black, with only a very slight whitening at the tip of the middle finger.

Ears.-Very large and broad, with numerous transverse, arcuate plications; tragus broad, with thickened anterior border and with single notch on anterior border and one tooth on posterior border, lacking the serrations seen in auritus.

Skull.-Similar in all details to that of auritus.

Measurements (from dried skin).-Total length, approximately, $115 \mathrm{~mm}$.; tail vertebræ, 40 ; hind foot, with claws, 16.3 ; forearm, estimated from two fragments, 84 ; height of ear from base of tragus, 28.2; height of tragus, 8.5 ; greatest breadth of tragus, 4.3 .

Skull.-Breadth of braincase, 10.6 ; least interorbital breadth, 4.2 ; zygomatic breadth, 13.2; breadth of palate across $\mathrm{m}^{3}, 9.0$; length of upper toothrow, $\mathrm{c}-\mathrm{m}^{3}$, 9.4 ; length of mandible, 16.6 ; length of lower toothrow, $\mathrm{c}-\mathrm{m}_{3}, 10.7$.

Colombianus is readily distinguishable from auritus not only by the marked difference in color but by the much wider, thicker tragus, which lacks the serrated margins seen in Peters's figures ${ }^{6}$ and also noticeable in a specimen of auritus from Bonda, Colombia. The lack of white on the wing tips serves to separate it from auritus guiance, ${ }^{7}$ while auritus australis described in the same paper as the foregoing species, evidently has the same color pattern as auritus since Thomas makes no mention of any color difference and bases the separation of the new subspecies upon the amount of white on the wing tip.

In the color pattern of the under parts, the throat and abdomen being lighter than the adjacent regions, is seen a possible approach toward the white throated species, $C_{\hookrightarrow}$. carrikeri. Carrikeri, however, differs conspicuously from colombianus in color and also in details of ear structure, having a smaller ear and more slender tragus.

\section{Histiotus inambarus sp. nov.}

Type, No. 37194, Dept. of Mammalogy, + , Peru, Rio Inambari $\left(70^{\circ} 15^{\prime} \mathrm{W} ., 13^{\circ}\right.$ $55^{\prime}$ S.), altitude 2200 feet, March 12, 1915; collectors, Messrs. H. and C. Watkins. The type is a skin in fair condition with a slightly crushed skull.

General characters. - Similar in size and general characters to Histiotus macrotus but coloration paler, ears narrower and less convex along inner margin.

Color.-Above uniform Saccardo's umber, the hairs noticeably darker at the

${ }^{6}$ Abhandl. k. preuss. Akad. Wissensch. Berlin, 1865, p. 305.

${ }^{7}$ Ann. and Mag. Nat. Hist. (7), XVI, p. 308, 1905. 
base, and with small postauricular patches of much lighter colored hair which are the same color as the underparts; below, everywhere light buff of Ridgway, the hairs darker at the base. Ears and membranes black.

Ears.-Very large and broad; connected by a very low ridge, scarcely discernable on the crown; inner margin well rounded at base but not conspicuously so; outer margin evenly convex from tip to base; tragus very tall, simple. Ears crossed by a number of transverse folds which appear as fine lines, seven visible on the upper and eight on the lower side.

Skull.-Normal for the genus.

Measurements. - (compared with those of velatus, in parentheses): Total length, $108 \mathrm{~mm}$. (112); tail vertebræ, 52 (55); height of ear from base of tragus (dried skin), 26.7 (24.3, macrotus, 26.3); greatest breadth of ear, 17.7 (19.4, macrotus, 19.1); length of forearm, 48.3 (46.8, macrotus, 48.3).

Inambarus most closely resembles macrotus from which it may be readily distinguished, however, by its lighter color and differently shaped ear. The ear of macrotus has a wide and abrupt expansion at the base on the inner margin, in this respect only exceeded in the genus by velatus. The ear of inambarus, however, is more evenly rounded at the base of the inner margin and is somewhat narrower, especially at the base, than in macrotus. Also the ear of the new species is very black, contrasting with the yellowish color of the ear in the only adult specimen of macrotus available for comparison. As this specimen of macrotus is an alcoholic perhaps too much stress had best not be made on this point.

Inambarus differs even more apparently from velatus and montanus in coloration and ear characters than it does from macrotus. 


\section{$2 \mathrm{BHL}$ Biodiversity Heritage Library}

Anthony, H. E. 1920. "New Rodents and New Bats from Neotropical Regions." Journal of mammalogy 1, 81-86. https://doi.org/10.2307/1373748.

View This Item Online: https://www.biodiversitylibrary.org/item/220052

DOI: https://doi.org/10.2307/1373748

Permalink: https://www.biodiversitylibrary.org/partpdf/90491

\section{Holding Institution}

Smithsonian Libraries

\section{Sponsored by}

Biodiversity Heritage Library

\section{Copyright \& Reuse}

Copyright Status: Not in copyright. The BHL knows of no copyright restrictions on this item.

This document was created from content at the Biodiversity Heritage Library, the world's largest open access digital library for biodiversity literature and archives. Visit BHL at https://www.biodiversitylibrary.org. 